\title{
Supramolecular assembly based on a heteropolyanion: Synthesis and crystal structure of $\mathrm{Na}_{3}\left(\mathrm{H}_{2} \mathrm{O}\right)_{6}\left[\mathrm{Al}(\mathrm{OH})_{6} \mathrm{Mo}_{6} \mathrm{O}_{18}\right] \cdot 2 \mathrm{H}_{2} \mathrm{O}$
}

\author{
VADDYPALLY SHIVAIAH and SAMAR K DAS* \\ School of Chemistry, University of Hyderabad, Hyderabad 500 046, India \\ e-mail: skdsc@uohyd.ernet.in
}

MS received 8 November 2004; revised 25 December 2005

\begin{abstract}
Synthesis and structural characterization of a polyoxometalate compound $\mathrm{Na}_{3}\left(\mathrm{H}_{2} \mathrm{O}\right)_{6}$ $\left[\mathrm{Al}(\mathrm{OH})_{6} \mathrm{Mo}_{6} \mathrm{O}_{18}\right] \cdot 2 \mathrm{H}_{2} \mathrm{O}(\mathbf{1})$ have been described. Compound 1 exhibits three-dimensional network structure in the solid state, which is assembled by Anderson-type heteropolyanions, $\left[\mathrm{Al}(\mathrm{OH})_{6} \mathrm{Mo}_{6} \mathrm{O}_{18}\right]_{n}^{3 n-}$, as building blocks sharing sodium cations. 1 possesses "sinuous" channels occupied by supramolecular water dimers as guests. Anderson anions, sodium-coordinated water and crystal water are additionally involved in an intricate hydrogen-bonding network in the crystal of $\mathbf{1}$.
\end{abstract}

Keywords. Anderson-type heteropolyanions; sodium cation as linkers; three-dimensional network structure; guest supramolecular water dimers; hydrogen-bonding interactions.

\section{Introduction}

Synthesis of new materials, formed via supramolecular assemblies based on metal oxide-based well-defined building units and with new physical properties in the solid state, is a challenging task in modern inorganic chemistry. ${ }^{1}$ Polyoxometalates are interesting in this respect, as they can form metal oxide-based building blocks which can be linked to network structures with cavities and pores. ${ }^{2}$ In recent years, polyoxometalates are intensely being explored because of their applications as new materials, structural aesthetics, ${ }^{2}$ catalysts $^{3}$ and biologically active compounds. ${ }^{4}$ Heteropolyanions of general formulae $\left[\mathrm{X}^{n+}(\mathrm{OH})_{6} \mathrm{Mo}_{6} \mathrm{O}_{18}\right]^{(6-n)-}$ (protonated form; $\mathrm{X}=$ heteroatom, e.g. $\left.\mathrm{Al}^{3+}, \mathrm{Cr}^{3+}, \mathrm{Co}^{3+}, \mathrm{Cu}^{2+}\right)$ and $\left[\mathrm{X}^{n+} \mathrm{Mo}_{6} \mathrm{O}_{24}\right]^{(12-n)-}$ (non-protonated form; $\mathrm{X}=$ heteroatom, e.g. $\mathrm{Te}^{5+}, \mathrm{I}^{7+}$ ), known as Anderson-type anions, ${ }^{5}$ constitute a special class of polyoxometalate compounds have been of increasing interest. ${ }^{6}$ A number of Anderson anions have been reported and some of them were structurally characterized. ${ }^{7,8}$ They are mostly discrete cluster-like structures; but reports of compounds, where Anderson-type heteropolyanions are linked to extended structures, are very few. ${ }^{9}$ We report here the synthesis and characterization of a three-dimensional coordination

\footnotetext{
*For correspondence
}

polymer, $\quad \mathrm{Na}_{3}\left(\mathrm{H}_{2} \mathrm{O}\right)_{6}\left[\mathrm{Al}(\mathrm{OH})_{6} \mathrm{Mo}_{6} \mathrm{O}_{18}\right] \cdot 2 \mathrm{H}_{2} \mathrm{O} \quad$ (1), which includes guest water dimers in its ' $\mathrm{S}$ '-shaped channels. A preliminary report of this result has already appeared. ${ }^{10}$ We describe here the detailed structural description of $\mathbf{1}$, including the complicated hydrogenbonding network that involves the $-\mathrm{OH}$ groups of Anderson anions, sodium-coordinated and the guest water molecules.

\section{Experimental section}

Double-distilled water was used throughout. All other chemical reagents were of analytical grade purity. TGA analyses were performed on a Shimadzu DTG-50 thermal analyser under nitrogen atmosphere at a scan rate of $1^{\circ} \mathrm{C} \mathrm{min}^{-1}$. Powder X-ray diffraction spectra were recorded using $\mathrm{Cu}-\mathrm{K} \alpha(\lambda=1.54 \AA)$ radiation on a Phillips PW 3710 diffractometer at a scanning speed of $2 \cdot 4^{\circ} \mathrm{min}^{-1}$. The number of $\mathrm{Al}$ and $\mathrm{Na}$ sites, revealed by single-crystal X-ray structure analysis, is consistent with the result of EDAX analysis (Philips XL 30). The differential scanning calorimetry (DSC) experiments were conducted using a Perkin-Elmer DSC-4 calorimeter at a heating rate of $10^{\circ} \mathrm{C} \mathrm{min}$. Hydrogen was analysed using a Perkin-Elmer model 240C elemental analyser. Infrared spectra were recorded by using $\mathrm{KBr}$ pellets and a Jasco-5300 FT-IR spectrophotometer. 
2.1 Synthesis of $\mathrm{Na}_{3}\left(\mathrm{H}_{2} \mathrm{O}\right)_{6}\left[\mathrm{Al}(\mathrm{OH})_{6} \mathrm{Mo}_{6} \mathrm{O}_{18}\right]$. $2 \mathrm{H}_{2} \mathrm{O}(\mathbf{1})$

To a solution of $\mathrm{AlCl}_{3} \cdot 6 \mathrm{H}_{2} \mathrm{O}(1.5 \mathrm{~g}, 6 \cdot 21 \mathrm{mmol})$ in $25 \mathrm{ml}$ of water which was acidified with $10 \mathrm{ml}$ of acetic acid $(100 \%), \mathrm{Na}_{2} \mathrm{MoO}_{4} \cdot 2 \mathrm{H}_{2} \mathrm{O}(3.5 \mathrm{~g}, 14.46 \mathrm{mmol})$ was added and dissolved by stirring; the $\mathrm{pH}$ of the resulting clear solution was adjusted to 1.8 by the dropwise addition of $35 \%$ hydrochloric acid. The reaction mixture was kept at $20-22^{\circ} \mathrm{C}$ in an open $100 \mathrm{ml}$ conical flask. After one week the precipitated white crystals of 1 were filtered, washed with water and dried at room temperature in air. Yield: $2.0 \mathrm{~g}(68 \%$ based on Mo).

Selected data for 1: IR (KBr pellet) $\left(\overline{\mathrm{v}}, \mathrm{cm}^{-1}\right)$ : $1620 \mathrm{~m}\left\{\delta\left(\mathrm{H}_{2} \mathrm{O}\right)\right\}, 947 s / 920 s\{\mathrm{v}(\mathrm{Mo}=\mathrm{O})\}, 845 w, 650 s$, $574 m, 530 w, 447 w, 390 w$. Raman (KBr matrix) $(\bar{v}$, $\mathrm{cm}^{-1}$ ): $958 s, 890 m, 568 w, 362 m$, 224s. Anal. Calc. for $\mathrm{AlH}_{22} \mathrm{Mo}_{6} \mathrm{Na}_{3} \mathrm{O}_{32}$ (1205.77): $\mathrm{Na}, 5 \cdot 72 ; \mathrm{H}, 1.84 \%$. Found: $\mathrm{Na}, 5.69 ; \mathrm{H}, 1.79 \%$. The number of $\mathrm{Al}$ and $\mathrm{Na}$ sites revealed by $\mathrm{X}$-ray analysis is consistent with the result of EDAX analysis, which gives an average value of $\mathrm{Mo}: \mathrm{Al} \approx 6 \cdot 0$ and $\mathrm{Mo}: \mathrm{Na} \approx 2 \cdot 0$.

\subsection{Removal of guest and coordinated water molecules}

A freshly prepared sample of $\mathbf{1}(0 \cdot 25 \mathrm{~g})$ was heated at $125^{\circ} \mathrm{C}$ in a conventional oven for $2 \mathrm{~h}$. The measured weight loss $(0.021 \mathrm{~g})$ was equivalent to the loss of 6 water molecules per formula unit (calcd 0.0224 g). This supports the formulation of the desolvated compound as $\mathrm{Na}_{3}\left(\mathrm{H}_{2} \mathrm{O}\right)_{2}\left[\mathrm{Al}(\mathrm{OH})_{6} \mathrm{Mo}_{6} \mathrm{O}_{18}\right]$. This is in agreement with the elemental analysis. Anal. Found (calcd): Na, 6.35 (6.28); H, 1.05 (0.92)\%. This result is consistent with the first weight loss in the TGA curve (vide infra). The X-ray powder diffraction pattern of $\mathrm{Na}_{3}\left(\mathrm{H}_{2} \mathrm{O}\right)_{2}\left[\mathrm{Al}(\mathrm{OH})_{6} \mathrm{Mo}_{6} \mathrm{O}_{18}\right]$ reveals a new phase compared to that of $\mathbf{1}$. This is not surprizing because once sodium-coordinated monodentate water molecules are gone, some rearrangement of sodium coordination takes place with the formation of a new phase. This is consistent with the fact that compound $\mathbf{1}$ on heating shows an endothermic phase transition $\left(80-125^{\circ} \mathrm{C}\right.$; peak $94^{\circ} \mathrm{C}$ ) in the DSC curve. The enthalpy change of this transformation was estimated to be $208 \mathrm{~kJ} \mathrm{~mol}^{-1}$ by differential scanning calorimetry. Although it is a new phase, its IR spectrum is quite similar to that of $\mathbf{1}$, suggesting a similar type of framework in $\mathrm{Na}_{3}\left(\mathrm{H}_{2} \mathrm{O}\right)_{2}$ $\left[\mathrm{Al}(\mathrm{OH})_{6} \mathrm{Mo}_{6} \mathrm{O}_{18}\right]$. Compound $\mathbf{1}$ could not be regenerated from this new phase (as indicated by X-ray powder diffraction studies) on resolvation at room temperatue. The resolvation experiment was performed in a vacuum desiccator containing the dehydrated sample $\mathrm{Na}_{3}\left(\mathrm{H}_{2} \mathrm{O}\right)_{2}\left[\mathrm{Al}(\mathrm{OH})_{6} \mathrm{Mo}_{6} \mathrm{O}_{18}\right]$ and water separately.

\subsection{Thermogravimetric analysis (TGA)}

TGA performed on $\mathbf{1}$ showed a sharp weight loss $(8.5 \%)$ at $\sim 50^{\circ} \mathrm{C}$ and this corresponded to the loss of 5.7 water molecules per formula unit. Then the lower hydrate remained stable up to $180^{\circ} \mathrm{C}$. Another weight loss $(7.6 \%)$ was observed between 180 and $300^{\circ} \mathrm{C}$, suggesting the loss of five water molecules (calcd $7.46 \%$ ). The second weight loss occurred with the decomposition of the Anderson anion because five water molecules, associated with the second loss, include $6 \mathrm{OH}^{-}$groups attached to the central aluminum. No attempt was made to identify the products of decomposition. TGA curve confirmed the loss of a total of 11 water molecules (total weight loss: 16.55\%; calcd $16 \cdot 42 \%$ ) per formula unit.

\section{$2.4 X$-ray crystallographic analysis for compound 1}

Crystals of 1 were removed from the mother liquor and immediately cooled to $183(2) \mathrm{K}$ on a Bruker AXS SMART diffractometer (three circle goniometer with $1 \mathrm{~K} \mathrm{CCD}$ detector, Mo-K $\alpha$ radiation, graphite monochromator). Hemisphere data were collected in $\omega$ at $0.3^{\circ}$ scan width at a detector distance of $5 \mathrm{~cm}$. An empirical absorption correction using equivalent reflections was performed with the program SADABS. The structure was solved using SHELXS-9 $7^{11}$ and refined using SHELXL- $97^{12}$ to $R l=0.0215, w R 2=0.0536$ for 9885 reflections with $I>2 \sigma(I)$. All non-hydrogen atoms were refined anisotropically. Hydrogen atoms were located from difference Fourier maps and refined isotropically. However, the hydrogen atoms on $\mathrm{O}(46), \mathrm{O}(47)$ and $\mathrm{O}(48)$ became unstable during refinement, and therefore the corresponding $\mathrm{O}-\mathrm{H}$ distances were constrained at $0.96 \AA$. This original cell was transformed to a smaller cell $(a=6 \cdot 4776(2) \AA, \quad b=10 \cdot 8548(3) \AA$, $c=10.8549(3) \AA ; \quad \alpha=109.3800(10)^{\circ}, \quad \beta=95.43^{\circ}$, $\left.\gamma=106 \cdot 79^{\circ} ; V=673 \cdot 80(3) \AA^{3}\right)$ based on the unit cell dimension of the known similar compound $\mathrm{Na}_{3}\left[\mathrm{Cr}(\mathrm{OH})_{6} \mathrm{Mo}_{6} \mathrm{O}_{18}\right] \cdot 8 \mathrm{H}_{2} \mathrm{O}$ (ref. 9a: $a=10.9080(4) \AA$, $b=0.9807(4) \AA, c=6.4679(2) \AA ; \alpha=107.594(2)^{\circ}$, $\left.\beta=84.438(2)^{\circ}, \gamma=112.465(3)^{\circ}\right)$ but the structure, obtained using a smaller cell, manifested disorder of 
sodium and one oxygen atom. The sodium atoms are situated a little apart from the "ideal" positions and that is why the larger cell describes the situation more precisely. The crystallographic data are summarized in table 1. Further details of the crystal structure investigation may be obtained from the Fachinformationszentrum, Karlsruhe, D-76344 Eggenstein-Leopoldshafen, Germany (fax: (+49) 7247-808-666; e-mail: crysdata@ fiz-karlsruhe.de), on quoting the depository number CSD-415139.

\section{Results and discussion}

The synthesis of $\mathbf{1}$ was performed at relatively low $\mathrm{pH}$ value in contrast to the preparations of other Anderson type compounds reported earlier. ${ }^{7,8}$ Compound 1 was prepared by treating an acidified aqueous solution of $\mathrm{AlCl}_{3}$ with sodium molybdate. White crystals of $\mathbf{1}$ were characterized by elemental analysis, IR spectroscopy, thermogravimetry and unambiguously by single crystal X-ray structure analysis.

Table 1. Crystal data and structure refinement for $\mathbf{1}$.

\begin{tabular}{ll}
\hline Formula & $\mathrm{H}_{22} \mathrm{AlMo}_{6} \mathrm{Na}_{3} \mathrm{O}_{32}$ \\
Formula weight & $1205 \cdot 77$ \\
Crystal class & Triclinic \\
Space group & $P \overline{1}$ \\
$Z$ & 3 \\
Cell constants & \\
$a$ & $12 \cdot 0618(3) \AA$ \\
$b$ & $13 \cdot 1570(4) \AA$ \\
$c$ & $14 \cdot 1563(4) \AA$ \\
$\alpha$ & $80 \cdot 7850(10)^{\circ}$ \\
$\beta$ & $75 \cdot 2660(10)^{\circ}$ \\
$\gamma$ & $68 \cdot 9210(10)^{\circ}$ \\
$V$ & $2021 \cdot 43(10) \AA^{3}$ \\
$\mu$ & $2 \cdot 913 \mathrm{~mm}{ }^{-1}$ \\
Crystal size (mm) & $0 \cdot 20 \times 0 \cdot 18 \times 0 \cdot 08$ \\
$D_{\text {calc }}$ & $2 \cdot 971 \mathrm{~g} / \mathrm{cm}^{3}$ \\
$F(000)$ & 1728 \\
Theta range & \\
$\quad$ for data collection & $1 \cdot 66$ to $29 \cdot 99^{\circ}$ \\
Limiting indices & $-16 \leq h \leq 16,-18 \leq k \leq 18$, \\
& $-19 \leq l \leq 19$ \\
Reflections collected & 28895 \\
Unique reflections & $11686\left(R_{\text {int }}=0 \cdot 0187\right)$ \\
Refinement method & Full-matrix least-squares on $F^{2}$ \\
Number of parameters & 679 \\
Goodness-of-fit on $F^{2}$ & $1 \cdot 058$ \\
Final $R$ indices $(I>2 \sigma(I))$ & $R 1=0 \cdot 0215, w R 2=0 \cdot 0536$ \\
$R$ indices (all data $)$ & $R 1=0 \cdot 0279, w R 2=0 \cdot 0562$ \\
Largest diff. peak & \\
$\quad$ and hole $\left(e \AA^{3}\right)$ & $1 \cdot 453$ and $-1 \cdot 013$ \\
\hline & \\
&
\end{tabular}

The crystallographic unit cell contains 1.5 molecules as an asymmetric unit (figure 1). This shows the coordination environment of the Anderson anion, $\left[\mathrm{Al}(\mathrm{OH})_{6} \mathrm{Mo}_{6} \mathrm{O}_{18}\right]^{3-}$ which coordinates sodium cation via $\mathrm{Mo}=\mathrm{O}$ terminal oxygen atoms. The Anderson heteropoly anion consists of seven edge-sharedoctahedra, six of which are Mo-octahedra arranged hexagonally around the central octahedron containing heterometal ion (for example $\mathrm{Al}^{3+}$ in the present case) at the centre (figure 1). Bond lengths and bond angles within the Anderson anion of $\mathbf{1}$ (table 2) are consistent with values found for other Anderson anions. The crystal structure of 1 shows three-dimensional framework having "sinuous" channels (figure 2), which is constructed by Anderson-type anions as building blocks sharing sodium cations (figure 1). The threedimensional framework is formed by stacking of two-dimensional layers (figure 3a) that are linked laterally by sodium-water chains running in between these layers (figure $3 b$ ) through the coordination of $\mathrm{Mo}=\mathrm{O}$ terminal oxygen atoms of Anderson anions. In the layer (figure $3 a$ ), each polyanion acts as a hexadentate ligand co-ordinating four $\mathrm{Na}^{+}$ions around it through six terminal oxygen atoms of four $\mathrm{MoO}_{4}(\mathrm{OH})_{2}$ octahedra. In other words, the co-ordination site of each $\mathrm{Na}^{+}$ion in the layer is a distorted octahedron formed by two terminal oxygen atoms in

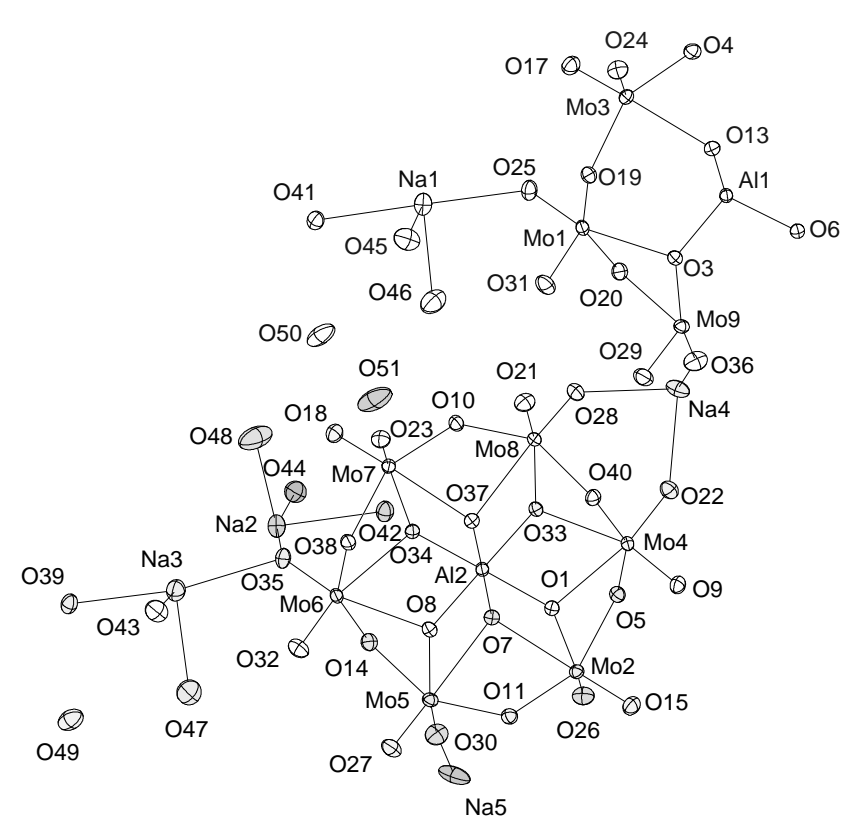

Figure 1. Asymmetric unit (as 1.5 molecules) in 1. Sodium coordination of the Anderson anion via terminal oxygen atoms on molybdenum is shown. Thermal ellipsoids at $50 \%$ probability. 
Table 2. Selected bond lengths $(\AA)$ and angles $\left({ }^{\circ}\right)$ for $\mathbf{1}$.

Bond lengths $(\AA)$

\begin{tabular}{|c|c|c|c|}
\hline $\operatorname{Mo}(1)-\mathrm{O}(31)$ & $1 \cdot 7020(14)$ & $\operatorname{Mo}(1)-\mathrm{O}(25)$ & $1 \cdot 7209(14)$ \\
\hline $\mathrm{Mo}(1)-\mathrm{O}(3)$ & $2 \cdot 2929(13)$ & $\mathrm{Mo}(2)-\mathrm{O}(15)$ & $1 \cdot 6987(14)$ \\
\hline $\mathrm{Mo}(2)-\mathrm{O}(26)$ & $1 \cdot 7208(14)$ & $\mathrm{Mo}(2)-\mathrm{O}(11)$ & $1.9152(13)$ \\
\hline $\mathrm{Mo}(3)-\mathrm{O}(24)$ & $1 \cdot 7239(14)$ & $\mathrm{Mo}(3)-\mathrm{O}(4)$ & $1.9064(13)$ \\
\hline $\mathrm{Mo}(4)-\mathrm{O}(22)$ & $1 \cdot 7053(14)$ & $\mathrm{Mo}(4)-\mathrm{O}(9)$ & $1 \cdot 7194(14)$ \\
\hline $\mathrm{Mo}(5)-\mathrm{O}(30)$ & $1 \cdot 6981(14)$ & $\mathrm{Mo}(5)-\mathrm{O}(27)$ & $1 \cdot 7072(14)$ \\
\hline $\mathrm{Mo}(6)-\mathrm{O}(14)$ & $1.9192(13)$ & $\mathrm{Mo}(6)-\mathrm{O}(38)$ & $1 \cdot 9401(13)$ \\
\hline $\mathrm{Mo}(7)-\mathrm{O}(18)$ & $1 \cdot 7042(14)$ & $\mathrm{Mo}(7)-\mathrm{O}(23)$ & $1 \cdot 7197(13)$ \\
\hline $\mathrm{Mo}(8)-\mathrm{O}(21)$ & $1 \cdot 7082(14)$ & $\mathrm{Mo}(8)-\mathrm{O}(28)$ & $1 \cdot 7116(14)$ \\
\hline $\mathrm{Mo}(9)-\mathrm{O}(29)$ & $1 \cdot 7044(14)$ & $\mathrm{Mo}(9)-\mathrm{O}(36)$ & $1 \cdot 7126(14)$ \\
\hline $\mathrm{Al}(1)-\mathrm{O}(3)$ & $1 \cdot 8904(13)$ & $\mathrm{Al}(1)-\mathrm{O}(6)$ & $1 \cdot 8947(13)$ \\
\hline $\mathrm{Al}(2)-\mathrm{O}(1)$ & $1 \cdot 8930(14)$ & $\mathrm{Al}(2)-\mathrm{O}(8)$ & $1 \cdot 8938(14)$ \\
\hline $\mathrm{O}(25)-\mathrm{Na}(1)$ & $2 \cdot 4339(16)$ & $\mathrm{O}(28)-\mathrm{Na}(4)$ & $2 \cdot 4707(14)$ \\
\hline $\mathrm{O}(35)-\mathrm{Na}(3)$ & $2 \cdot 5167(16)$ & $\mathrm{O}(36)-\mathrm{Na}(4)$ & $2 \cdot 3008(14)$ \\
\hline $\mathrm{Na}(1)-\mathrm{O}(46)$ & $2 \cdot 3620(18)$ & $\mathrm{Na}(1)-\mathrm{O}(45)$ & $2 \cdot 430(2)$ \\
\hline $\mathrm{Na}(2)-\mathrm{O}(44)$ & $2 \cdot 417(2)$ & $\mathrm{Na}(2)-\mathrm{O}(42)$ & $2 \cdot 4506(17)$ \\
\hline \multicolumn{4}{|l|}{ Bond angles $\left(^{\circ}\right)$} \\
\hline $\mathrm{O}(31)-\mathrm{Mo}(1)-\mathrm{O}(25)$ & $105 \cdot 64(7)$ & $\mathrm{O}(31)-\mathrm{Mo}(1)-\mathrm{O}(19)$ & $98 \cdot 00(7)$ \\
\hline $\mathrm{O}(25)-\mathrm{Mo}(1)-\mathrm{O}(19)$ & $99 \cdot 88(6)$ & $\mathrm{O}(31)-\mathrm{Mo}(1)-\mathrm{O}(20)$ & $99 \cdot 48(6)$ \\
\hline $\mathrm{O}(15)-\mathrm{Mo}(2)-\mathrm{O}(11)$ & $98 \cdot 89(6)$ & $\mathrm{O}(26)-\mathrm{Mo}(2)-\mathrm{O}(11)$ & $102 \cdot 51(6)$ \\
\hline $\mathrm{O}(17)-\mathrm{Mo}(3)-\mathrm{O}(24)$ & $106 \cdot 24(7)$ & $\mathrm{O}(17)-\mathrm{Mo}(3)-\mathrm{O}(4)$ & $99 \cdot 08(6)$ \\
\hline $\mathrm{O}(24)-\mathrm{Mo}(3)-\mathrm{O}(4)$ & $101 \cdot 71(6)$ & $\mathrm{O}(17)-\mathrm{Mo}(3)-\mathrm{O}(19)$ & $99 \cdot 55(6)$ \\
\hline $\mathrm{O}(30)-\mathrm{Mo}(5)-\mathrm{O}(14)$ & $98 \cdot 93(6)$ & $\mathrm{O}(27)-\mathrm{Mo}(5)-\mathrm{O}(14)$ & $101 \cdot 78(6)$ \\
\hline $\mathrm{O}(32)-\mathrm{Mo}(6)-\mathrm{O}(35)$ & $104 \cdot 92(7)$ & $\mathrm{O}(32)-\mathrm{Mo}(6)-\mathrm{O}(14)$ & $101 \cdot 53(6)$ \\
\hline $\mathrm{O}(18)-\mathrm{Mo}(7)-\mathrm{O}(10)$ & $98 \cdot 82(6)$ & $\mathrm{O}(23)-\mathrm{Mo}(7)-\mathrm{O}(10)$ & $101 \cdot 89(6)$ \\
\hline $\mathrm{O}(21)-\mathrm{Mo}(8)-\mathrm{O}(28)$ & $105 \cdot 34(7)$ & $\mathrm{O}(21)-\mathrm{Mo}(8)-\mathrm{O}(40)$ & $101 \cdot 90(6)$ \\
\hline $\mathrm{O}(29)-\mathrm{Mo}(9)-\mathrm{O}(20)$ & $101 \cdot 79(6)$ & $\mathrm{O}(36)-\mathrm{Mo}(9)-\mathrm{O}(20)$ & $101 \cdot 68(6)$ \\
\hline $\mathrm{O}(29)-\mathrm{Mo}(9)-\mathrm{O}(3)$ & $90 \cdot 56(6)$ & $\mathrm{O}(36)-\mathrm{Mo}(9)-\mathrm{O}(3)$ & $163 \cdot 72(6)$ \\
\hline $\mathrm{Al}(2)-\mathrm{O}(1)-\mathrm{Mo}(4)$ & $104 \cdot 40(6)$ & $\mathrm{Mo}(2)-\mathrm{O}(1)-\mathrm{Mo}(4)$ & $93 \cdot 72(5)$ \\
\hline $\mathrm{O}(48)-\mathrm{Na}(2)-\mathrm{Na}(3)$ & $81 \cdot 95(7)$ & $\mathrm{O}(44)-\mathrm{Na}(2)-\mathrm{Na}(3)$ & $151 \cdot 50(6)$ \\
\hline $\operatorname{Mo}(6)-\mathrm{O}(38)-\mathrm{Mo}(7)$ & $115 \cdot 39(7)$ & $\mathrm{Mo}(8)-\mathrm{O}(40)-\mathrm{Mo}(4)$ & $117 \cdot 16(7)$ \\
\hline
\end{tabular}

Table 3. Geometrical parameters of hydrogen bonds ( $\AA$, deg) for the nearlinear water dimer and its association with host (see figure 4) in $\mathbf{1 .}$

\begin{tabular}{lllll}
\hline $\mathrm{D}-\mathrm{H} \ldots \mathrm{A}$ & $d(\mathrm{D}-\mathrm{H})$ & $d(\mathrm{H} \ldots \mathrm{A})$ & $d(\mathrm{D} \ldots \mathrm{A})$ & $<(\mathrm{DHA})$ \\
\hline $\mathrm{O}(49)-\mathrm{H}(49 \mathrm{~A}) \mathrm{O} \ldots(50) \# 2$ & $0 \cdot 87(4)$ & $1 \cdot 99(4)$ & $2 \cdot 843(3)$ & $170(3)$ \\
$\mathrm{O}(49)-\mathrm{H}(49 \mathrm{~B}) \ldots \mathrm{O}(4) \# 3$ & $0 \cdot 74(4)$ & $2 \cdot 15(4)$ & $2 \cdot 815(2)$ & $149(4)$ \\
$\mathrm{O}(39)-\mathrm{H}(39 \mathrm{~B}) \ldots \mathrm{O}(49)$ & $0 \cdot 86(3)$ & $1 \cdot 82(3)$ & $2 \cdot 650(2)$ & $163(3)$ \\
$\mathrm{O}(47)-\mathrm{H}(47 \mathrm{~A}) \ldots \mathrm{O}(49)$ & $1 \cdot 00^{\mathrm{a}}$ & $1 \cdot 87$ & $2 \cdot 817(3)$ & 157.2 \\
$\mathrm{O}(50)-\mathrm{H}(50 \mathrm{~A}) \ldots \mathrm{O}(46)$ & $0 \cdot 91(4)$ & $2 \cdot 18(4)$ & $2 \cdot 938(3)$ & $141(3)$ \\
$\mathrm{O}(50)-\mathrm{H}(50 \mathrm{~B}) . . \mathrm{O}(11) \# 1$ & $0 \cdot 74(4)$ & $2 \cdot 08(4)$ & $2 \cdot 754(2)$ & $150(4)$ \\
$\mathrm{O}(41)-\mathrm{H}(41 \mathrm{~B}) . . \mathrm{O}(50)$ & $0 \cdot 81(3)$ & $1 \cdot 87(3)$ & $2 \cdot 664(2)$ & $165(3)$ \\
\hline
\end{tabular}

${ }^{\mathrm{a}}$ Restrained; $\mathrm{D}=$ donor; $\mathrm{A}$ = acceptor.

Atoms with additional labels \#1, \#2 and \#3 are related by symmetry operations: \#1 $x-1, y, z$; \#2 $-x,-y,-z+1$; \#3 $x-1, y-1, z+1$. 
Table 4. Geometrical parameters of hydrogen bonds ( $\AA$, deg) among the Anderson anions (see figure 5).

\begin{tabular}{lccll}
\hline $\mathrm{D}-\mathrm{H} \ldots \mathrm{A}$ & $d(\mathrm{D}-\mathrm{H})$ & $d(\mathrm{H} \ldots \mathrm{A})$ & $d(\mathrm{D} \ldots \mathrm{A})$ & $<(\mathrm{DHA})$ \\
\hline $\mathrm{O}(1)-\mathrm{H} \ldots \mathrm{O}(39) \# 1$ & $0 \cdot 82(3)$ & $1 \cdot 81(3)$ & $2 \cdot 625(2)$ & $174(3)$ \\
$\mathrm{O}(37)-\mathrm{H}(37) \ldots \mathrm{O}(38) \# 3$ & $0 \cdot 80(3)$ & $2 \cdot 18(3)$ & $2 \cdot 9706(19)$ & $168(3)$ \\
$\mathrm{O}(8)-\mathrm{H}(8) \ldots \mathrm{O}(23) \# 3$ & $0 \cdot 76(3)$ & $2 \cdot 00(3)$ & $2 \cdot 734(2)$ & $163(3)$ \\
$\mathrm{O}(34)-\mathrm{H}(34) \ldots \mathrm{O}(42)$ & $0 \cdot 81(4)$ & $1 \cdot 84(4)$ & $2 \cdot 634(2)$ & $170(4)$ \\
$\mathrm{O}(7)-\mathrm{H}(7) \ldots \mathrm{O}(19) \# 2$ & $0 \cdot 82(3)$ & $2 \cdot 17(3)$ & $2 \cdot 974(2)$ & $166(3)$ \\
$0(33)-\mathrm{H}(33) \ldots \mathrm{O}(24) \# 2$ & $0 \cdot 76(3)$ & $1 \cdot 99(3)$ & $2 \cdot 753(2)$ & $173(3)$ \\
\hline
\end{tabular}

$\mathrm{D}=$ donor; $\mathrm{A}=$ acceptor.

Atoms with additional labels \#1, \#2 and \#3 are related by symmetry operations: \#1 $x+1, y, z ; \# 2 x, y-1, z ; \# 3-x+1,-y,-z+1$.

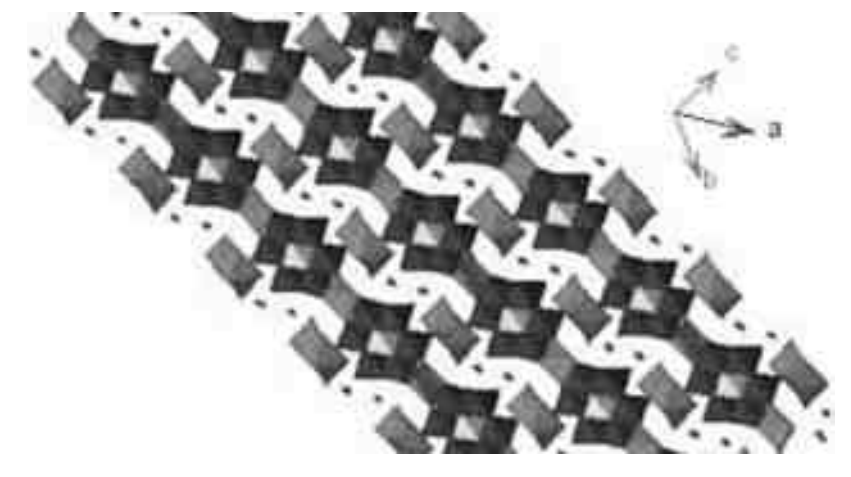

Figure 2. Illustration of the "sinuous" channels occupied by guest water molecules, including supramolecular water dimers in the polymer framework of $\mathbf{1}$.

trans (axial) positions from two Anderson anionunits and the equatorial positions of the octahedron are co-ordinated by four terminal oxygen atoms from the two different Anderson anions. The sodium-water chain (figure 3b) can be thought to be formed as follows. Two terminal oxygen atoms of two different Anderson anions from the respective layers bridge two sodium ions, each of which is additionally coordinated to three water molecules making them co-ordinatively unsaturated (i.e. penta-coordinated sodium ions) as shown in scheme 1 . The coordination saturation of each sodium ion is then achieved by interlinking of these dimers via $\mu_{2}$-type aqua bridge leading thereby to one dimensional sodium chain, which runs in between these layers (scheme 2).

In the chain, each sodium is octahedrally coordinated and shares two edges from two opposite sides ( $2 \mathrm{O}$ and $2 \mathrm{H}_{2} \mathrm{O}$ respectively, figure $3 \mathrm{~b}$ ).

The resulting three-dimensional network accommodates guest water molecules in its " $\mathrm{S}$ "-shaped channels (figure 2). There are total 8 water mole-

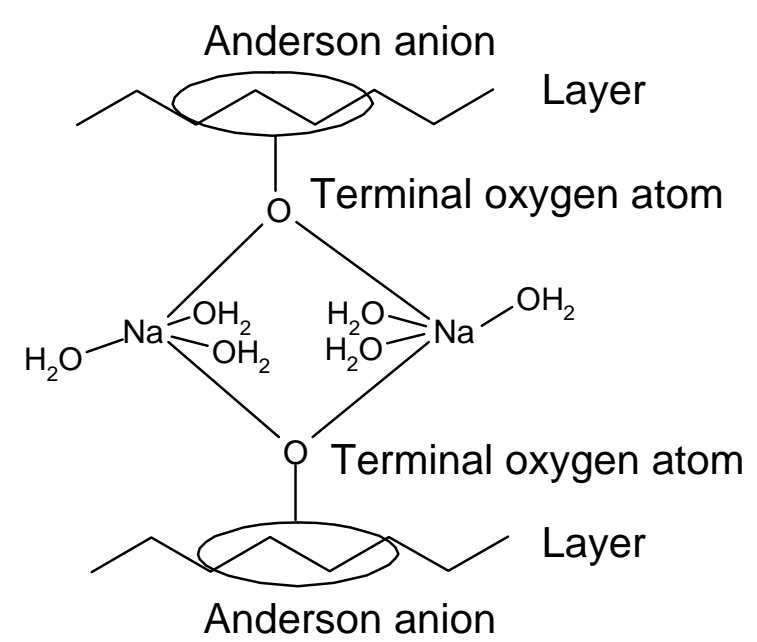

Scheme 1.

cules per formula unit of $\mathbf{1}$ (12 water molecules in the asymmetric unit consisting of 1.5 molecules). Among them, two water molecules (as guests) do not show any covalent interactions, but they are hydrogen-bonded to host channels (they are $\mathrm{O}(49), \mathrm{O}(50)$ and $\mathrm{O}(51)$ waters in the asymmetric unit of 1.5 molecules). Whereas $\mathrm{O}(49)$ and $\mathrm{O}(50)$ water molecules arrange themselves to form a water dimer, the $\mathrm{O}(51)$ water molecule is hydrogen-bonded to one of the sodium-coordinated waters. The rest of the six water molecules of $\mathbf{1}$ are coordinated to sodium cations, two of which (they are $\mathrm{O}(43), \mathrm{O}(44)$ and $\mathrm{O}(45)$ waters in the asymmetric unit) are coordinated in a $\mu_{2}$-type bidentate fashion (forming sodium-water chain) and the remaining four (namely $\mathrm{O}(39), \mathrm{O}(41), \mathrm{O}(42)$, $\mathrm{O}(46), \mathrm{O}(47)$ and $\mathrm{O}(48)$ waters in the asymmetric unit) are coordinated to sodium cations in the chain as monodentate ligands. The hydrogen-bonded water 


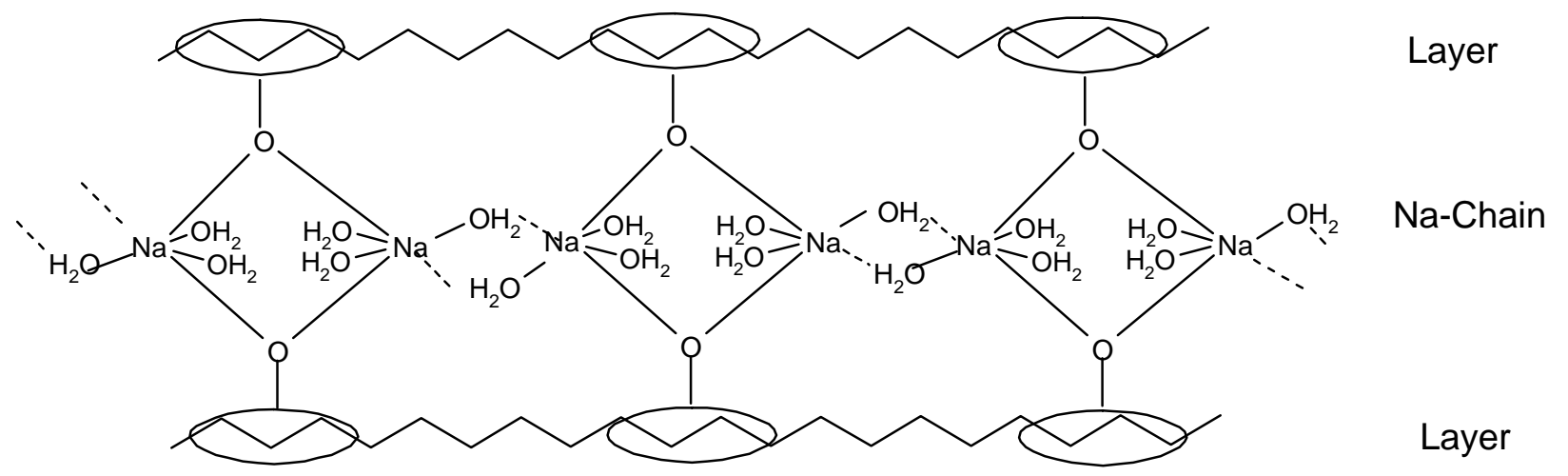

Scheme 2.
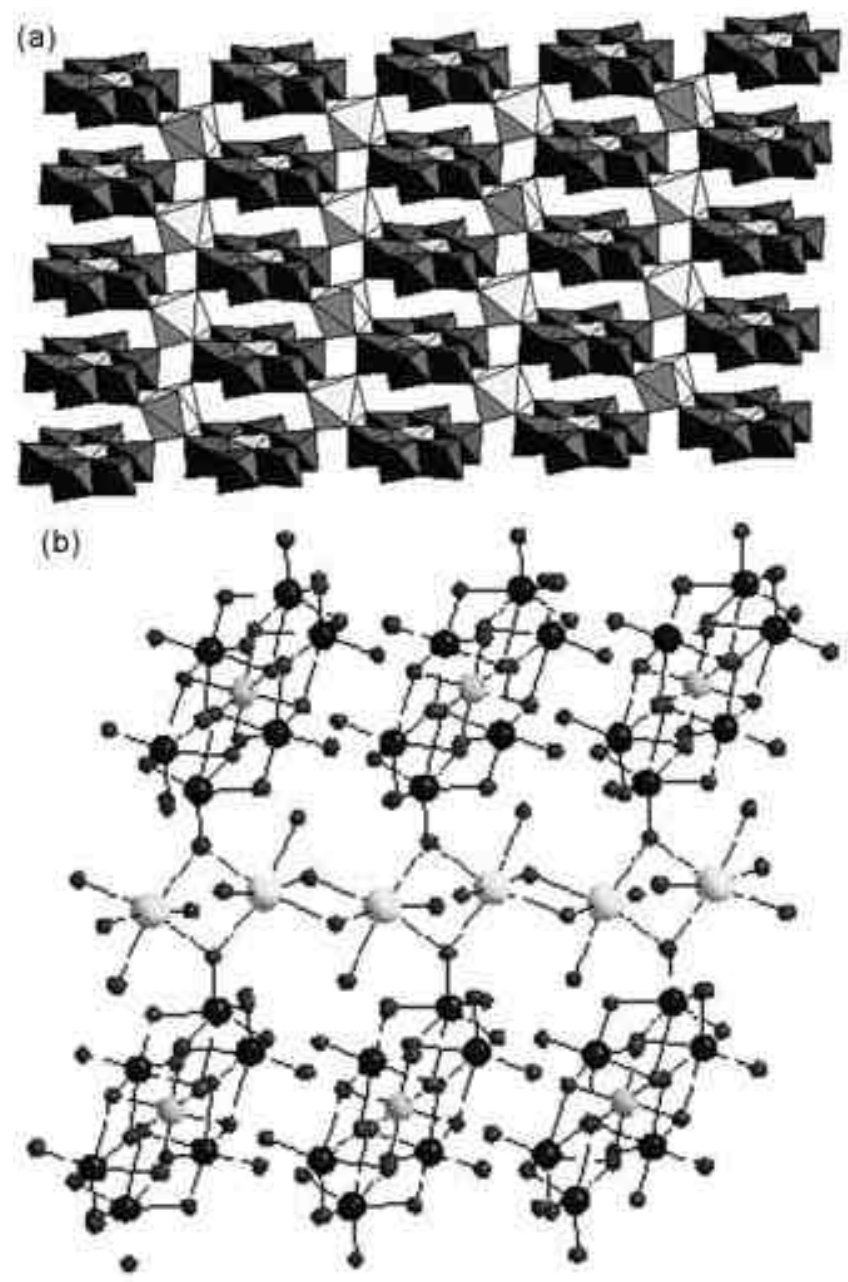

Figure 3. (a) Layer type of network formed by sodium octahedra and Anderson anions. (b) Sodium-water chain supported by the Anderson anions.

dimer (guest) and its association with host in the "S"-shaped channels (figure 2) are separately shown in figure 4 . The relevant hydrogen-bonding parameters are presented in table 3.

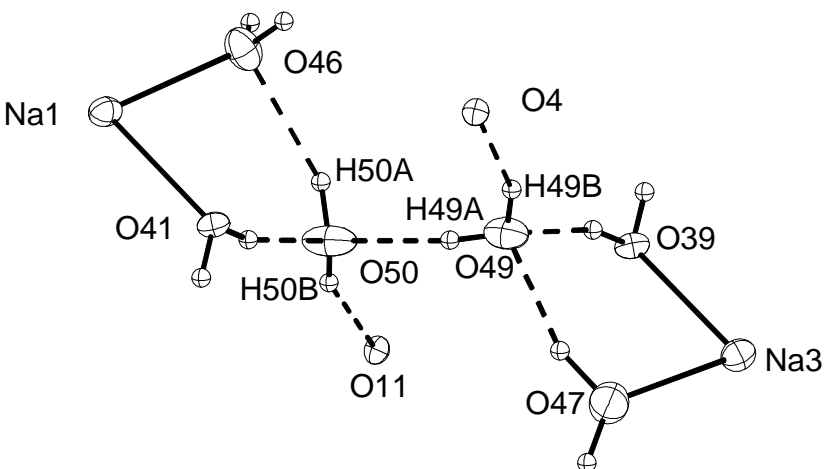

Figure 4. Representation of the supramolecular water dimer (guest) and its immediate environment (host) as found in 1 ( $50 \%$ thermal ellipsoids). Covalent chemical bonds are shown as solid lines and H-bonds as dashed lines. $\mathrm{O}(4)$ is bridging oxygen atom between two molybdenum atoms in an Anderson anion and $\mathrm{O}(11)$ is bridging oxygen atom of another Anderson anion (see figure 1). $\mathrm{O}(39), \mathrm{O}(41), \mathrm{O}(46)$ and $\mathrm{O}(47)$ are sodium-coordinated water ligands (part of the host), which show additional hydrogen bonding interactions with the guest water dimer.

In addition to these hydrogen bonding interactions between water dimer and the sodium-coordinated water molecules (figure 4), there exist $\mathrm{O}-\mathrm{H} . . . \mathrm{O}$ hydrogen bonds in between Anderson-anions (figure 5a) involving the coordinated hydroxide ions of the central $\mathrm{Al}(\mathrm{OH})_{6}$ moiety and the peripheral terminal and bridging oxygen atoms of the Anderson heteropolyanion. More specifically, three-coordinated hydroxides on each face of the heteropolyanion (e.g. H1, $\mathrm{H} 37, \mathrm{H} 8$ at one face and $\mathrm{H} 33, \mathrm{H} 7, \mathrm{H} 34$ at the other face as shown in figure 5b) are involved in hydrogen-bonded interactions, both above and below the face of the anion, which extend into a chain. One of the hydroxyl hydrogens on both faces are hydrogen bonded to water molecule coordinated to sodium chain. 

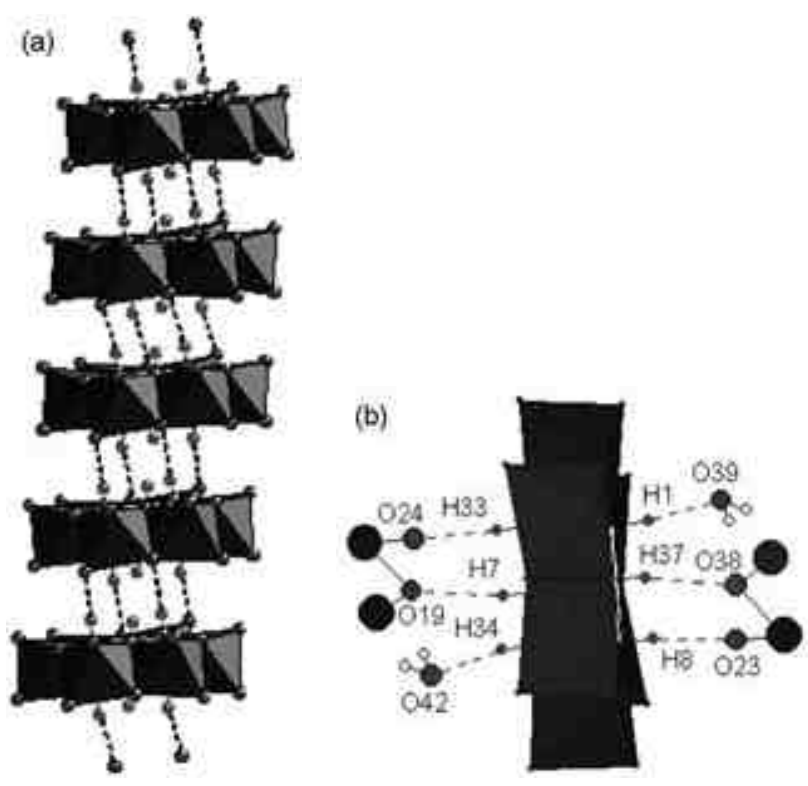

Figure 5. (a) Hydrogen bonding interactions among Anderson anions through $\mathrm{O}-\mathrm{H}$...O bonds. (b) Side view of an Anderson anion showing its hydrogen-bonding interactions that involve coordinated - $\mathrm{OH}$ groups of central $\left\{\mathrm{Al}(\mathrm{OH})_{6}\right\}$ moiety, bridging and terminal oxygen atoms of (adjacent) Anderson anions and sodium-coordinated waters.

\section{Conclusion}

In conclusion, a new type of supramolecular assembly has been described, which is formed from a heteropolyanion (as a building unit) sharing sodium cation as linker. This metal-oxide based material encapsulates supramolecular water dimers in its "sinuous" channels. An extensive hydrogen-bonding network is constructed by the interaction of the water molecules coordinated to sodium ions, the coordinated hydroxide ions of the central $\mathrm{Al}(\mathrm{OH})_{6}$ moiety of the Anderson anion, and the guest water molecules.

\section{Acknowledgements}

We thank the Department of Science and Technology, Government of India, for financial support. VS thanks the Council of Scientific and Industrial Research, New Delhi for a fellowship. We are grateful to University Grants Commission, New Delhi for providing infrastructure facility at University of Hyderabad under UPE Grant.

\section{References}

1. (a) Hagrman P J, Hagrman D and Zubieta J 1999 Angew. Chem., Int. Ed. Engl. 38 2638; (b) Cheetham A K, Ferey G and Loiseau T 1999 Angew. Chem., Int. Ed. Engl. 38 3268; (c) Richardson D and Groy T L 1998 Acc. Chem. Res. 31 474; (d) Zaworotko M J 2000 Angew. Chem., Int. Ed. Engl. 39 3052; (e) Janiak C 1997 Angew. Chem., Int. Ed. Engl. 36 1431; (f) Ferey G and Cheetham A K 1999 Science 283 1125; (g) Li H, Laine A, O'Keefe M and Yaghi O M 1999 Science 283 1145; (h) Davis M E 1997 Chem. Eur. J. 3 1745; (i) Chiang R-K, Huang C-C and Wur C-S 2001 Inorg. Chem. 40 3237; (j) Pan L, Woodlock E $\mathrm{B}$ and Wang X 2000 Inorg. Chem. 394174

2. (a) Müller A, Peters F, Pope M T and Gatteschi D 1998 Chem. Rev. 98 239; (b) Klemperer W G and Wakk C G 1998 Chem. Rev. 98 297; (c) Coronado E and Gomez-Garcia C J 1998 Chem. Rev. 98 273; (d) Pope M T and Müller A 1991 Angew. Chem., Int. Ed. Engl. 30 34; (e) Jeanin Y P 1998 Chem. Rev. 98 51; (f) Baker L C W and Glick D C 1998 Chem. Rev. 98 3; (g) Müller A and Serain C 2000 Acc. Chem. Res. 33 2; (h) Müller A and Kögerler P 1999 Coord. Chem. Rev. 182 3; (i) Cronin L, Kögerler P and Müller A 2000 J. Solid State Chem. 15257

3. Mizuno N and Misono M 1998 Chem. Rev. 9819

4. Rhule J T, Hill C L, Judd D A and Schinazi R F 1998 Chem. Rev. 98327

5. Anderson J S 1937 Nature (London) 140850

6. (a) Son J-H, Choi H and Kwon Y-U $2000 \mathrm{~J}$. Am. Chem. Soc. 122 7432; (b) Carrier X, Lambert J F and Che M 1997 J. Am. Chem. Soc. 11910137

7. (a) Baker L C W, Lebioda L, Grochowski J and Mukherjee H G 1980 J. Am. Chem. Soc. 102 3274; (b) Sergienko V S, Molchanov V N and PoraiKoshits M A 1979 Sov. J. Coord. Chem. 5740

8. (a) Kondo H, Kobayashi A and Sasaki Y 1980 Acta Crystallogr. B36 661; (b) Ito F, Ozeki T, Ichida H, Miyamae H and Sasaki Y 1989 Acta Crystallogr. C45 946; (c) Lee H Y, Park K M, Lee U and Ichida H 1991 Acta Crystallogr. C47 1959; (d) Evans H T Jr 1974 Acta Crystallogr. B30 2095; (e) Lebioda L, Ciechanowicz-Rutkowska M, Baker L C W and Grochowski J 1980 Acta Crystallogr. B36 2530

9. (a) Perloff A 1970 Inorg. Chem. 9 2228; (b) Rosu C and Dickman M H 1999 Acta Crystallogr. C55 11

10. Manikumari S, Shivaiah V and Das S K 2002 Inorg. Chem. 416953

11. Sheldrick G M 1997 SHELXS-97, Program for solution of crystal structures, University of Göttingen, Germany

12. Sheldrick G M 1997 SHELXL-97, Program for refinement of crystal structures, University of Göttingen, Germany 